Portland State University

PDXScholar

$11-22-2019$

\title{
Report on the 2018 Impact Study of Recreational Park Use on the Nesting Success of Actinemys marmorata, Chrysemys picta bellii, and Trachemys scripta elegans
}

Joseph Gayaldo

Portland State University

Follow this and additional works at: https://pdxscholar.library.pdx.edu/honorstheses Let us know how access to this document benefits you.

\section{Recommended Citation}

Gayaldo, Joseph, "Report on the 2018 Impact Study of Recreational Park Use on the Nesting Success of Actinemys marmorata, Chrysemys picta bellii, and Trachemys scripta elegans" (2019). University Honors Theses. Paper 809.

https://doi.org/10.15760/honors.828

This Thesis is brought to you for free and open access. It has been accepted for inclusion in University Honors Theses by an authorized administrator of PDXScholar. Please contact us if we can make this document more accessible: pdxscholar@pdx.edu. 
Report on the 2018 Impact Study of Recreational Park Use on the Nesting Success of Actinemys marmorata, Chrysemys picta bellii, and Trachemys scripta elegans

\title{
by
}

\section{Joseph Gayaldo}

An undergraduate honors thesis submitted in partial fulfillment of the requirements for the degree of

\author{
Bachelor of Science \\ in \\ University Honors \\ and \\ Environmental Science
}

Thesis Adviser

Sue Beilke

Portland State University

2019 
Disclaimer: Due to the sensitive nature of data regarding at risk species, no maps or discernable location indicators will be given in this report other than imagery presented at a coarse resolution. I will refer to the study site as the Park and the city as City.

Introduction: In June and July 2018 , I, in collaboration with the Audubon Society volunteers, City park managers, and the Oregon Department of Fish and Wildlife, conducted turtle nesting surveys at three known nesting sites in the Park in order to discern the effects of recreational park use on turtle nesting success, and turtle nesting behavior. This study was conducted to aid the City in their development of a ten-year habitat management plan, as well as inform and contribute to their overarching conservation and restoration efforts by the City. We observed two nesting attempts with one being successful, eleven attempted nests, and three predated nests. Other than the two observed attempts, we don't know the species association with any of the other nest types, or if they can be associated with particular females, which may make multiple nesting attempts.

Background: The Park hosts three species of turtles, the Western Painted Turtle, Chrysemys picta bellii (C.p. bellii), the Western Pond Turtle, Actinemys marmorata (A. marmorata), and the Red-eared Slider, Trachemys scripta elegans (T.s. elegans). C.p. bellii and A. marmorata are native to the region and both are listed as sensitive species by the state of Oregon ("Western Painted Turtle"; "Western Pond Turtle"). A. marmorata is federally listed as a species of concern and is currently under review for listing on the Endangered Species Act (Western pond Turtle (Actinemys marmorata)"). T.s. elegans is an invasive species. The historic distribution of C.p. bellii was from Oregon north through British Columbia, and east through Montana (Barela and Olson). A. marmorata's historic distribution was from Baja California north through southern British Columbia on the west side of the Cascades (Barela and Olson). T.s. elegans is native to the Mississippi River drainage and was listed by the IUCN as one of the top 100 invaders in the world ("Red-Eared Slider"; Boudielas et al.).

Both native turtle species are relatively long lived ( $>40$ years) and produce clutches of approximately ten eggs, with the potential for two clutches to be laid per season (Beilke). They tend to lay their eggs from the late afternoon into the evening. It is generally accepted that in the Willamette Valley they nest from early to midsummer, depending on the weather; approximately mid-May through July, (Beilke). They both are relatively wary species that flee when disturbed while basking or nesting. 
T.s. elegans is larger than the native turtle species, and is less wary, giving it a greater chance of success in both basking and recruitment in busy park settings. This may contribute to the high proportion of T.s. elegans in the Park relative to the total number of turtles observed (Beilke). The lower wariness of T.s. elegans may also be a result of large specimens, which used to be pets and are used to people, being released into the park by visitors. They tend to nest more in the morning, opposite of native turtle species.

Increasing the populations of native turtles, particularly A. marmorata, is a conservation goal that is being worked on in a multiagency effort (Beilke). Successful recruitment, laying a clutch of eggs that results in emergent young, is key to that effort, and conservation practices promoting this must take place where the turtles are found. Major threats to this in the Park include: dogs on and off leashes, dogs swimming in the water, disturbance from trail users, people "rescuing" the turtles by picking them up and putting them back into the water, disturbance from people fishing, boaters, competition with T.s. elegans, and a lack of access to suitable nesting habitat.

Site descriptions: The Park is located in the Willamette Valley alongside a river. It is a large park with several sloughs and miles of trails throughout it. Much of the park has a history of industrial and or agricultural use. A portion of the park has been set aside as a closed conservation area with no trails.

Dock Site: The first site surveyed was classified as highly impacted by recreational use due to its small size and proximity to a main trail. Two asphalt paths go off from the main trail and converge into a single trail that goes down a j-shaped peninsula with a dilapidated fishing dock at the end. There is brush and small trees growing beside the path, with shallow sloped openings leading to the water by the trails' convergence and at the bend, and an open area with moderate slopes down to the water by the dock. Suitable turtle nesting habitat can be found between the two trail's convergence and the main trail, by the first opening, alongside the trail to the dock, in the open area by the dock, and in an open field on the other side of the main trail. A temporary mesh fence, which was put up as a result of 2015 basking surveys in the park indicating that it might decrease human disturbance at known nesting sites, blocked access to this site from the main trail, (Figure 1) (Beilke). 


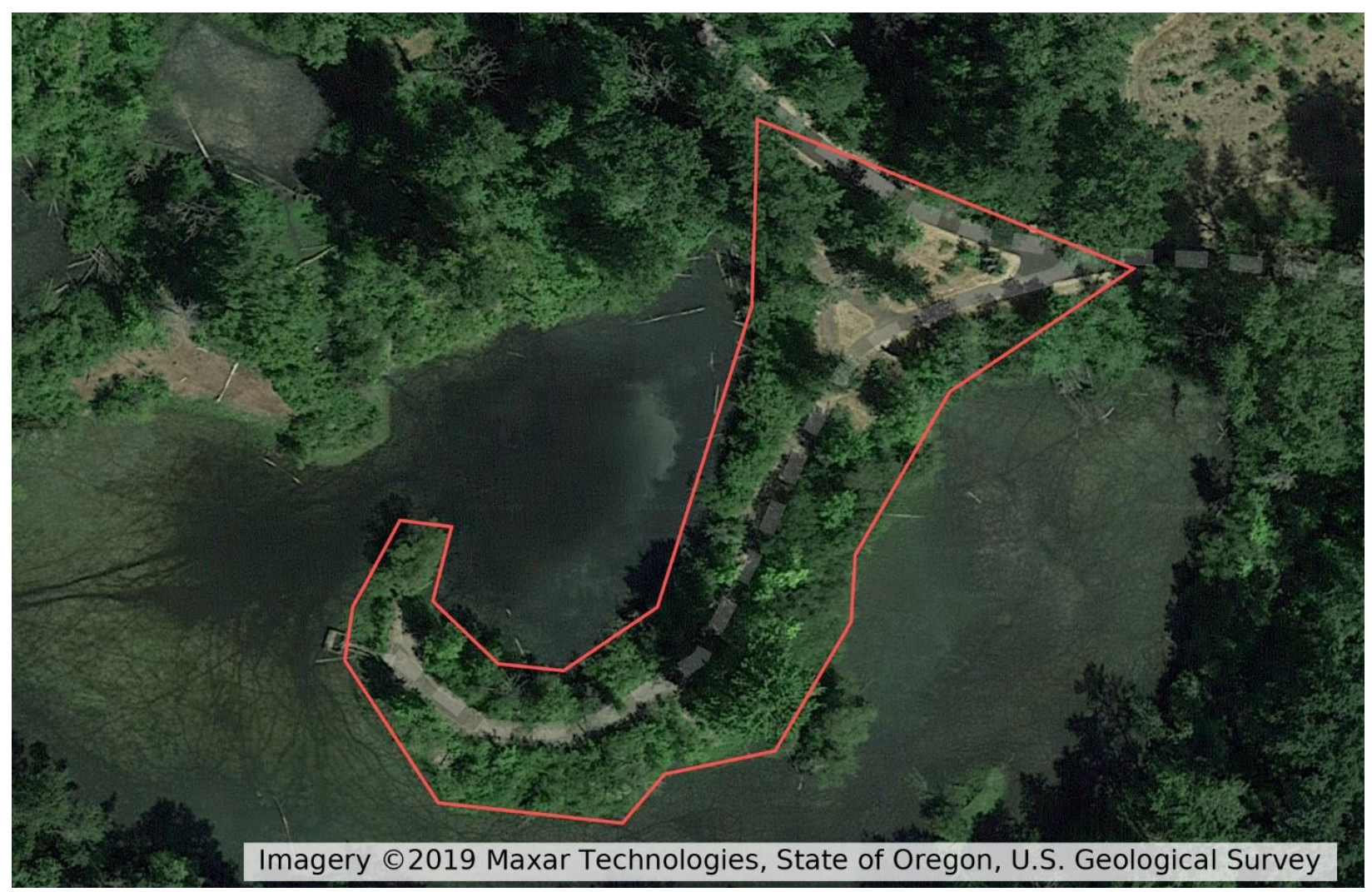

Figure 1: Satellite imagery of the Dock site.

Area C: The second site we surveyed was classified as moderately impacted by recreational use due to being closed off with mesh fencing as a result of the 2015 surveys, and the only evidence of use found being litter from people fishing. It is located approximately a half mile down the main trail from the Dock Site and has four tiers. The first tier is a small field alongside a main trail that is roughly rectangular in shape and is approximately 15 meters by 10 meters. The first grassy field is surrounded by blackberry brambles on one side and dense forested underbrush on the other, both of which converge to a small opening leading down to another field that is about twice its size. This second grassy field has a dense forested area around approximately $2 / 3$ of it. Both fields have loamy clay soil. Opposite of the path leading down to the second field is small hill, approximately four meters high on either side and two meters wide at the top, with a slough on the far side. There are openings on the top and bottom of the hill leading to a third open area that has far less grass and is flush against the slough. At the far end of the third area there is a small path leading to a fourth opening alongside the slough. Both the third and fourth openings have mostly sandy loam soils, with some grass and shrubs. See Figure 2 for an aerial image. 


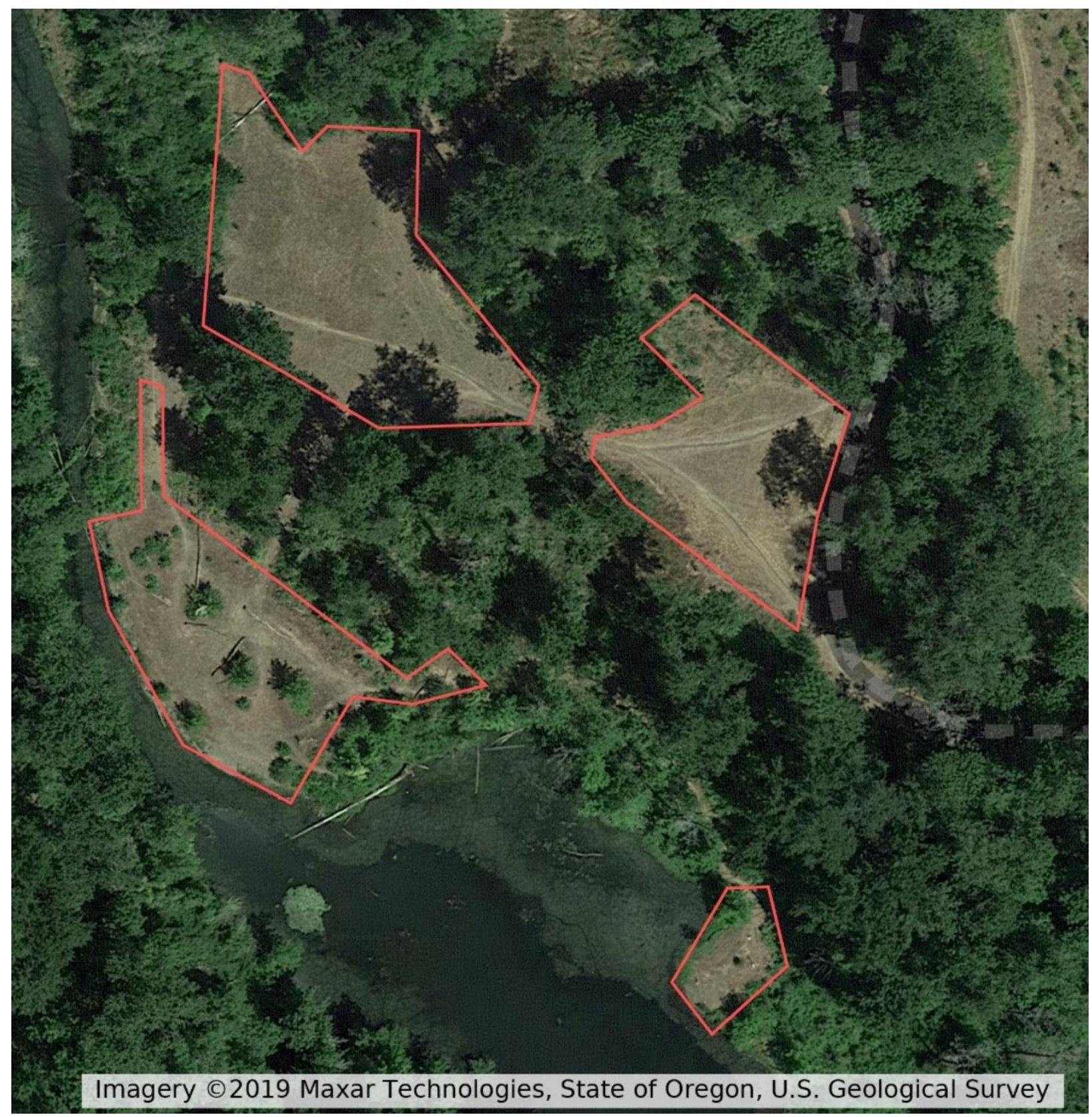

Figure 2: Satellite imagery of Area C.

Closed Site: The Closed Site is classified as minimally impacted by recreational park use. It is located approximately two miles north of the other two sites and has no official trails leading to it, however, there are some user made trails that go into parts of the conservation area. It has a small pond that is about $2 / 3$ surrounded by dense brush and shrubs, and $1 / 3$ by dense blackberry brambles. There is an intermittent stream bed that is approximately two meters wide going down to the pond in a very gentle slope. The stream bed is mainly sandy loam with a large field of dense grass on one side, and dense 
forest and underbrush on the other. Loamy clay soils in a relatively undisturbed location would be the ideal for nesting, however, there is none that is easily accessible to the turtles at this site.

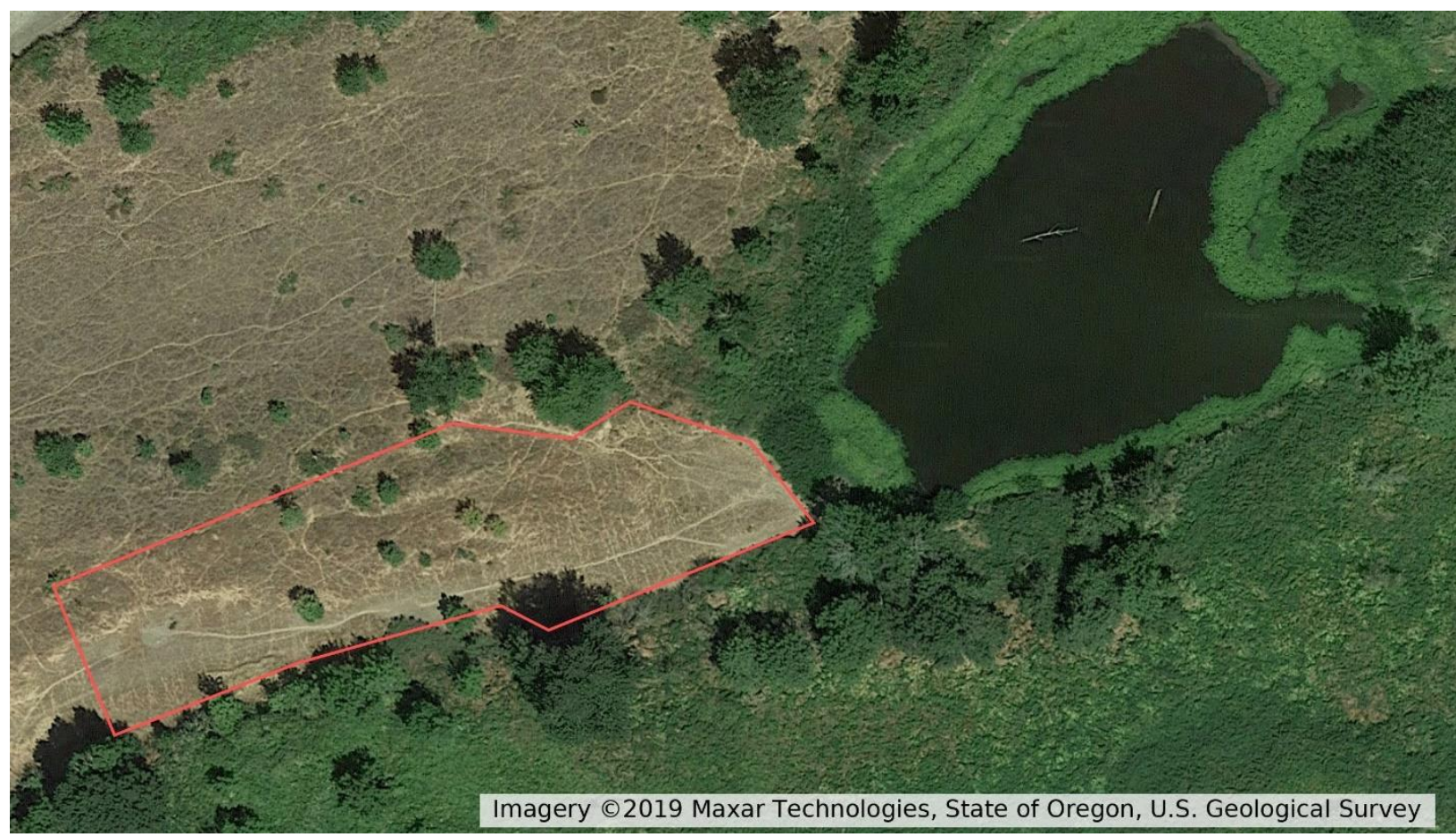

Figure 3: Satellite imagery of the Closed site.

Methods: Sue Beilke, State Biologist for ODFW, and I trained volunteers on turtle identification and field methods. The main training was on differentiating between C.p. bellii and T.s. elegans, as they are the easiest to get confused. Volunteers were also trained on how to ID an attempted and completed nest with imagery and a day in the field. Survey procedures were as follows: survey the Dock Site and Area C by walking in an "as the ox plows" pattern between 4:00 p.m. and 8:00 p.m. Surveys were to be completed, at a minimum, in pairs. If at any point a volunteer felt unsafe due to other people in the park, or wildlife, they were to leave immediately. Data to be retrieved on each survey included start and stop time in military format, areas surveyed, date, weather conditions, and the names of all the volunteers surveying (Figure 4). If the temperature was below $60^{\circ} \mathrm{F}$, or it was raining heavily, surveys would be canceled. Surveys took place from the beginning of June through July.

When volunteers found a turtle, nesting or walking around, they were to back off to a point that it couldn't see them and note the time. Volunteers were told not to tell the public that they were 


\begin{tabular}{|c|c|c|c|c|c|c|c|c|}
\hline Date: & & Observer: & & Start Weather: & & End Weather: & & \\
\hline Start time: & & End time: & & Start Temperature: & & End Temperature: & & \\
\hline $\begin{array}{l}\text { Observation } \\
\text { ID\# } \\
\end{array}$ & \begin{tabular}{|l|} 
Initial observation \\
time (military)
\end{tabular} & $\begin{array}{l}\begin{array}{l}\text { Species (pond, } \\
\text { paint, slider, } \\
\text { unknown) }\end{array} \\
\end{array}$ & \begin{tabular}{|l|} 
Behavior (Nesting, \\
Walking, Returning)
\end{tabular} & Location & $\begin{array}{l}\text { Nest category } \\
\text { (completed, predated, } \\
\text { attempted, in progress) }\end{array}$ & \# dogs on leash & \# dogs off leash & $\begin{array}{l}\text { \# biking/ } \\
\text { skateboarding/ } \\
\text { rollerblading }\end{array}$ \\
\hline 1 & & & & & & & & \\
\hline 2 & & & & & & & & \\
\hline 3 & & & & & & & & \\
\hline 4 & & & & & & & & \\
\hline 5 & & & & & & & & \\
\hline 6 & & & & & & & & \\
\hline 7 & & & & & & & & \\
\hline & \# boats or cars & \# walking/ running & $\begin{array}{l}\text { Response to People (no } \\
\text { change, freeze, flee, } \\
\text { other (describe)) }\end{array}$ & Start time of response & $\begin{array}{l}\text { Length of freeze/other } \\
\text { (minutes:seconds) ex. } \\
00: 46\end{array}$ & $\begin{array}{l}\text { Apparent reason for } \\
\text { response }\end{array}$ & $\begin{array}{l}\text { Departure time } \\
\text { (military) }\end{array}$ & $\begin{array}{l}\text { Reason for } \\
\text { departure }\end{array}$ \\
\hline 1 & & & & & & & & \\
\hline 2 & & & & & & & & \\
\hline 3 & & & & & & & & \\
\hline 4 & & & & & & & & \\
\hline 5 & & & & & & & & \\
\hline 6 & & & & & & & & \\
\hline 7 & & & & & & & & \\
\hline Match the ID & numbers betwe & es for each obs & ation. If turtle stops & starts multiple time & s go to next line. & & & \\
\hline Weather: & $\begin{array}{l}\text { Note the approxim } \\
\text { There will never be } \\
\text { Wind categories ca }\end{array}$ & $\begin{array}{l}\text { ate percent cloud cov } \\
\text { less than a light win } \\
\text { an be mixed. }\end{array}$ & $\begin{array}{l}\text { ver and the wind. Wind is lig } \\
\text { d. Moderate wind is branch }\end{array}$ & $\begin{array}{l}\text { ight, moderate, high. } \\
\text { hes swaying, more than }\end{array}$ & just leaf movement. High & wind is major tree mov & vement. & \\
\hline
\end{tabular}

Figure 4: Sample of data sheet that was used in the field.

surveying for turtles, or to inform them if they were watching one, even if the person's behavior would disturb the turtle. They were to note the time and location that they saw the turtle, and when it began nesting, if not doing so already. They were then to count the number of people that passed the turtle and the activity they were doing until the turtle completed the nest or left. Activities included: walking/jogging, biking, walking a dog, on or off leash, boaters, and people fishing.

They were also to note the behavior of the turtle for this period: the apparent reason for the behavior, if it was due to human activity, and the time at which it occurred. Behavior categories were: stops nesting then leaves, stops nesting and restarts, continues nesting until completion, and natural cause for stopping. If the turtles stopped and restarted or stopped and then left, volunteers were to use a timer and record the length of time the turtle stopped until changing its behavior. If the turtle stopped and started multiple times, volunteers were to go to the next line in the data sheet and continue recording. When the turtle left or finished nesting, volunteers were to note the time in military format. 
If the turtle was a T.s elegans, volunteers were to follow the above procedure with an extra step.

Following completion or nesting attempt, volunteers were to capture the turtle by hand and keep it in a five-gallon bucket until the end of the survey. On completion of the survey any T.s. elegans captured were to be turned in for euthanization by state veterinarians. Completed T.s. elegans nests were to be removed by a government official at a later date. I followed all of the above procedures for the Closed Site, which we did not ask volunteers to attempt to survey due to it being approximately a mile of off trail hiking to access.

\section{Findings and discussion:}

The dock site had the fewest number of nests found between the sites, however, it was the only site in which we found a turtle attempting to nest and completing it (Figure 5). The turtle was located by the

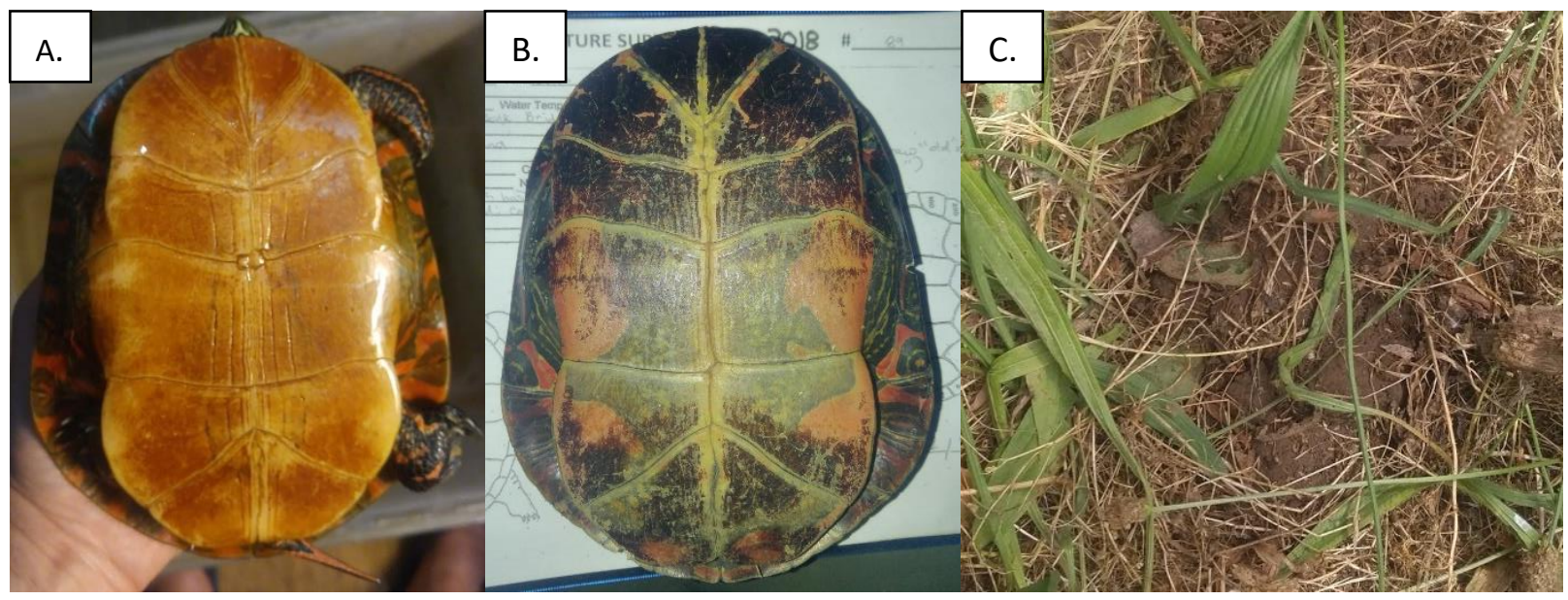

Figure 5: A. the plastron of the painted turtle that successful nested at the dock site. B. The plastron of a C.p. bellii. C. The completed nest by the turtle in A. The Midwest variety of painted turtles has the same dark markings of the Western Painted turtle, but limited to a thin strip in the center of its plastron, never extending to the margins.

convergence of trails near the first opening going down to the water. The species of turtle that made the nest could not be definitively determined. The plastron of the turtle differed from that normally found on C.p. bellii, and it may have been another variant of Chrysemys picta, potentially the Midwest variant. However, it did not fully match with the identifying plastron features of that variant either. We also found a highly unusual attempted nest at the dock site (Figure 6). A turtle of an unknown species attempted to nest, laid its eggs, and left

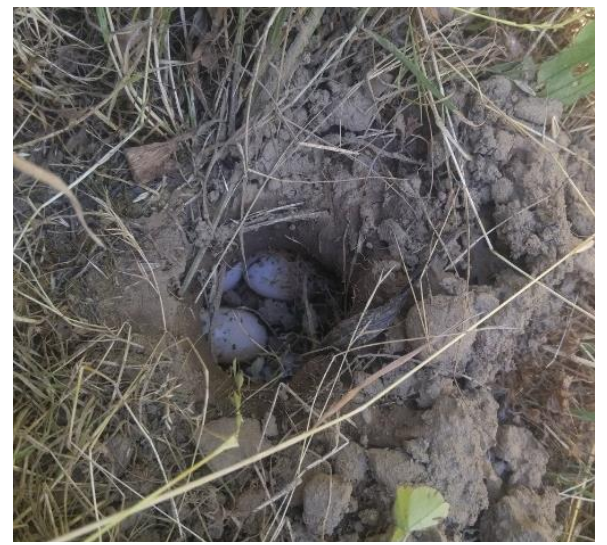

Figure 6: An attempted nest at the dock site. The turtle laid its eggs and fled without covering it due to some type of disturbance. 
without covering them. This is indicative of a major disturbance for the turtle to have left without covering its eggs. For example, I have seen a C.p. bellii continue to nest while a skunk was eating the eggs it was laying out from under it. It is also consistent with what was found in this park in 2015 basking and nesting surveys (Beilke). In one instance they observed a A. marmorata so distressed by pedestrian traffic that it was unable to attempt to nest beyond emptying its bladder to soften the soil.

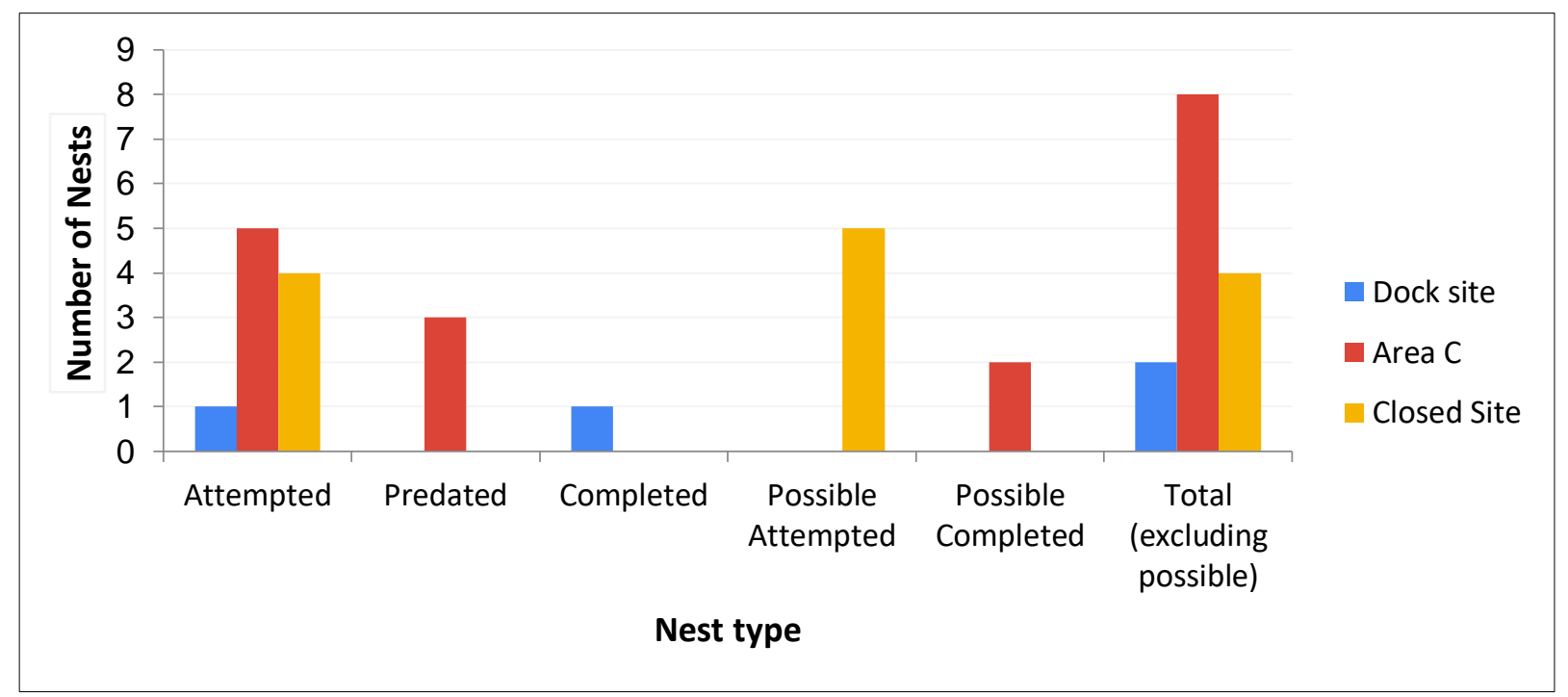

Figure 8: The number and type of nest found at each site.

We did not find any evidence of turtle use in the field located just beyond the main path by the dock site, which we included in each of our surveys of the site. The ground in the field is a loamy clay, which is perfect for nesting turtles. This is unusual because both C.p. bellii and A. marmorata can, and do, frequently travel further than the approximately 50 meters that is between the water that field when they are able to. I believe that the path acts like a wall to them due to the high amount of foot traffic it receives, and their wary nature. This severely limits their access to high quality nesting habitat near the dock site.

Area $\mathrm{C}$ had the most attempted, predated, and total nests of all types found; however, we did not find completed nests in this area (Figure 8). We did observe one C.p. bellii attempting to nest in this area, but it quit after hitting a rock (Figure 7). We did not find any nests in the first field. In the second field we found two possible completed nests, however the identifying features were

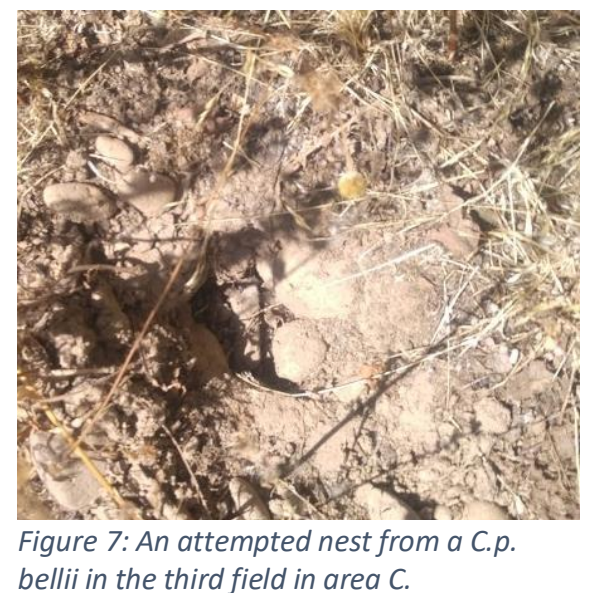


not clear enough to be certain. We found three attempted and one predated nest in the third opening, and three attempted and two predated nests in the small opening in the back. Both the third open area and the small opening were utilized by people fishing, evidenced by fishing related litter found there between surveys; there may have been other people accessing the first two fields as well, because someone knocked down the mesh fence between them.

We observed four attempted nests and five possible attempted nests in the closed conservation area. They were difficult to identify and locate unless they were in the sandy loam soil of the intermittent stream bed. This is largely because the field had thick tall grasses and an immense number of burrowing rodents. Their holes covered the area and looked very similar to a semi-degraded attempted nest. For that reason, we likely observed fewer nests than were present. This is further highlighted by the lack of predated nest observations in this area because it would be unlikely for there to be none in a relatively undisturbed site. We may also have had fewer total observations at the conservation site because we were only able to complete three surveys in that location; one at the end of June, one mid-July, and one to confirm previous observations at the Beginning of August. This was due to water levels being too high in the river to walk to the site on some days, being unable to take volunteers out there when they needed on the job training, and the extended process of getting to the site being outside the bounds of available time.

We were unable to do significant behavioral analysis on the data due to only having two actively nesting turtles observed. Further, we were unable to compare between species for the same reason. However, that does have important implications for turtle nesting success in the Park. We observed numerous turtles of all three species basking while doing these surveys, and a large number have been observed in previous years (Beilke). They have a significant amount of aquatic habitat and a large amount of potential suitable nesting habitat. This means that there must be a reason that so few turtles were observed in such good habitat. One significant observation about this is that the habitat the turtles were using to nest in each of the sites should be considered marginal. This is because the nests were mostly found quite close to the water, in habitat that is highly susceptible to flooding, which would kill any successful nests. It may be that they are nesting in other places that we do not know; as we found out that there is another site just outside the park that turtles are nesting in. It may be due to foot traffic disturbance, which is what I suspect for the dock area and the first two fields in Area C. Or, it could be some other factor. 
While we did not observe many turtles nesting, the ones we did observe were both Chrysemys picta spp. We did not directly observe any T.s. elegans nesting or attempting to nest. This is likely due to the study design, which focused on afternoon and evening turtle nesting, making it more likely that native turtles would be observed. We intentionally made this choice in the design of the study to bias data gathering toward native turtles, and to reduce travel time and workloads on ourselves and the volunteers, which was extensive. Future survey iterations should include morning and evening surveys, if possible, to more fully assess the turtle nesting success in the park and gather a more robust data set on the invasive turtles.

There were at least 13 survey days completed in the Dock Site and Area C during the approximately two months of turtle nesting season. However, there are an estimated 10 to 20 more that were completed as well. This was due to the way in which the volunteers interacted with the park. Most of them were regular park users before volunteering. Two of the volunteers that regularly used it would frequently check in on the areas to see if any turtles were either nesting, or if they could find any of new signs of turtles using the areas. They did not find any active turtles, but they did find some of the attempted and predated nests, which they conveyed to me, and I verified. Even though this was not to plan, it speaks to the engagement side of conservation. These volunteers enjoyed the project so much that they regularly participated in it in an unconventional way.

Recommendations: Adding mesh barriers was only partially successful in keeping people from entering the closed off areas of the park. Keeping people out, especially during nesting season, will be an important aspect for continued recruitment of native turtles. In the short term I recommend removing the asphalt and dock in the Dock Site and planting hedges alongside the main path to keep people out. Also, regularly mowing the grass, in the morning, in Area C could improve the fields as nesting habitat. Further, I recommend increasing outreach and engagement with the public regarding native turtles. This could take the form of guided nature walks where people learn to identify turtles, through continued monitoring projects for the people that want to help directly, and signs letting people know that we have sensitive species in their park and telling them what to do if they see one, as well as what they can do to help protect them. 
Long term, moving the main path that goes by Area $\mathrm{C}$ to the field outside of the forested area, visible in the top right of figure 2, and blocking the site off with hedges, could significantly improve the nesting habitat by removing the major human disturbance from that area. To address the concerns of people that fish at that site, I suggest adding new fishing docks to some of the larger ponds that don't have a significant number of basking logs. In the closed conservation area, I suggest going in with hand tools and removing a large area of the blackberry brambles. This would require regular maintenance to keep them down but could provide a significant increase to the overall suitable nesting habitat in that part of the park.

Conclusion: We surveyed areas within the park that were subjected to low, moderate, and high recreational park use impact. We found the most nests in the moderate impact area, however there were likely many nests that we did not find in the closed conservation area. In the short term I recommend closing off the sites that turtles are using to nest, and in the long term I recommend moving high impact paths, and continual maintenance of high value nesting areas. 
Works Cited

Barela, Kimberly L, and Deanna H Olson. "Mapping the Western Pond Turtle ( Actinemys Marmorata ) and Painted Turtle ( Chrysemys Picta ) in Western North America." Northwestern Naturalist, vol. 95, no. 1,2014 , pp. 1-12.

Beilke, Sue. Conservation Area and Park Turtle Survey Results - 2015 Final Report. Internal Report. City of $\square, 2017$.

---. Personal interview. Oct. 2019.

Boudjelas, Souyad, et al. 100 of the World's Worst Invasive Alien Species: A Selection from the Global Invasive Species Database. The International Union for Conservation of Nature, 2004, portals.iucn.org/library/node/8565.

"Red-Eared Slider." United States Department of Agriculture: National Invasive Species Information Center, www.invasivespeciesinfo.gov/profile/red-eared-slider.

"Western Painted Turtle." Oregon Conservation Strategy, oregonconservationstrategy.com/strategyspecies/western-painted-turtle/.

"Western pond Turtle (Actinemys marmorata)." U.S. Fish \& Wildlife Service, ecos.fws.gov/ecp0/profile/speciesProfile?spcode=C06B.

"Western Pond Turtle." Oregon Conservation Strategy, Oregon Department of Fish and Wildlife, oregonconservationstrategy.com/strategy-species/western-pond-turtle/. 